\title{
Motivation in Learning English through Blended Learning in the Electrical Engineering Department Manado State Polytechnic
}

\author{
Grace H. Pontoh \\ Electrical Engineering Department \\ Manado State Polytechnic
}

\author{
Maya E.I. Munaiseche \\ Electrical Engineering Department \\ Manado State Polytechnic
}

\begin{abstract}
This study aimed to determine the orientation that motivates students at Electrical Engineering Department of Manado State Polytechnic to learn English through the blended learning method and how the students' attitudes towards the applied model. This study is quantitative and qualitative. The data collection method is through a questionnaire based on a measuring instrument developed by Gardner, namely The Attitude/ Motivation Test Battery (AMTB). Data were analyzed and tested based on a Likert scale. Based on the results of tests on 31 students majoring in electrical engineering, the survey results showed that $56,48 \%$ stated that a better job opportunity would encourage student motivation in learning English through Blended-Learning. The results and discussion founded types of student motivation that are dominantly integrative and instrumental motivation towards blended learning based on Gardner's theory.
\end{abstract}

\section{Keywords}

1. Motivation, 2.learning, 3. Blended

\section{INTRODUCTION}

Motivation in learning English can be used to explain the success or failure of learning a second language around the world. [1]. Some experts agree that the theory of motivation related to the factors that drive behavior and give direction to that behavior, is generally acceptable, that is, a person's motives for engaging in a particular activity are based on the underlying needs. There are several studies or scientific papers written about the importance of motivation in learning English, Maslow said that motivation is the key to learning English in general. There are so many web-based learning models developing today. Some use web media as a supplement or addition, some use web media as a substitute for some face-to-face learning in class. [2]. Likewise, as stated by Gardner and Gagne, one of the factors believed to build that motivation is the attitude towards the language and culture of the people who use the language [3] suggests three aspects of attitude as follows:

1. Cognitive component, which refers to a person's beliefs about an object;

2. The affective component, which refers to the number of positive or negative feelings a person has for a particular object;

3. The behavioral component, which refers to the intention of someone's behavior or refers to the actual behavior towards the object.
The English proficiency of students majoring in Electrical Engineering is different [4]. Likewise, the motivation in learning English varies.

Learning English is important for students in Electrical Engineering. Students tend not to be familiar now. Teachers must develop motivation in learning English. The students find sometimes very difficult when studying in class. Most students think that English is challenging because they have to know the meaning of some words, and they can't speak it fluently [5]. According to Mc Pheat [6] this motivation is someone's description of one's motives for acting. This means that teachers must provide techniques or approaches to increase student motivation. Developing student motivation in higher education is difficult, especially in English language learning for specific students. The teacher must provide the best method/technique so that students can comfortably learn English in class. Most teachers teach English using textbooks; then they will explain verbally.

Blended learning is a necessity for students in the 21 st century because this technique combines learning and collaboration online. Even though many students use new technology such as cell phones so that they can easily obtain information. In addition, students embed technological devices into their world of life such as in school, they consider it a source of culture. By using smartphones, they can get applications to assist them in learning English. But it could be not to help them without motivation. Blended learning will help teachers know the quality of students in learning English.

Blended learning will help students easily determine to improve their skills such as academic writing, critical reading, communication for each student and teacher, and so on. Moreover, blended learning is not only possible to use in a single subject matter but also in multiple learning settings. The teacher must also be able to build interactions between students and other students inside the class, and between students and teachers to actively learn English. On-campus, teachers can build student interactions with face-to-face discussions, and they can use them online devices such as discussion forums, virtual conferences, and virtual worlds because it can improve their communication and practical learning in the classroom. [7]. Speaking skills in English for electrical engineering students Manado State Polytechnic do not have a strong foundation, there are four obstacles: types of panic, difficult to memorize, slow, and low self-confidence. So the student needs motivation from the teachers to offer the solution..

\section{METHOD}

The method of this research is a qualitative research which is 
aimed at revealing blended learning for students' motivation in studying the English language. The researcher explained the implementation of theories in finding and discussion. The supporting sources are taken from books, journals, and many others related to the topic. The stages of the research to be performed include the study of literature, observation, design research instruments, determination of research instruments, primary and secondary data collection. Data Analysis using a Likert scale. A survey of the motivation modified from 20 items adapted from Gardner's Attitude / Motivation Test Battery (AMTB) already done. Data were analyzed using Likert scale.

\section{RESULT AND DISCUSSION}

Technology in Electrical Engineering students at Manado State Polytechnics has several important roles:

First, they were used as an alternative teaching media. Technology is also used to develop student-centered learning. Technology provides access for students to study on their own. Students can organize teaching based on their speed of learning. Technology always offers collaborative learning processes based on ICT. The blended learning model places our students at the center of the learning process. Collaborative models face-to-face and online will increase student motivation during the learning process, having various technology platforms.

The learning needs of participants to increase the confidence to use English and the ability to speak English in daily activity. In the first preparation of learning materials model dialogue and various activities to increase vocabulary English. These materials are conveyed in softcopy for independent learning.

The second steps use the platform Classroom Google, Grup Whatsapp to control grup experience and support learning English activities using the blended-learning method.

The third preparation is document learning support. Documents supporters in this activity include student attendance lists and online learning schedules, and face-toface learning schedules. English Book is important to be prepared for support English learning activities using the blended-learning method. This preparatory stage makes students motivated and confident in learning English.

According to Saliba,et al. (2013: 4).[8] They state that blended learning is a systematic and strategic approach. That is combining face-to-face modes and online learning interactions in many disciplines. The definition is based on Watson et al. (2015: 5). They define blended learning as a type of hybrid learning. That is a combination of traditional teaching and online mode. Moreover, it is to achieve a more personalized and teaching-learning process.[9]. Blended learning to give the motivation for student effective interaction during the learning process. Based on the three definitions above, it can be concluded that blended learning is a model of learning which combines the positives of traditional fashions such as face-to-face with enhancements use of technology to maintain, engage student motivation during the learning process. Then, using online technology can increase student motivation. This can turn a more effective pedagogy into course design.

The blended learning model is becoming a new star in teaching practice because of several advantages (Saliba et al., 2013:30)[10]. First, blended learning increases learning access to learning materials and activities. The activities of Blended Learning also do better learning experiences for students. By having a better learning experience, students will have better results.
Integrated blended learning also has a beneficial impact on teachers and staff; because they will have new skills in management and teaching practice. Another advantage of the blended learning model is discussed by Bath \& Bourke (2010: 21) [11]. They stated which integrates learning support and enhances teacher roles, student experiences, and social environment. The technology used in blended learning can expand the available space to learn, engage, and motivate students through interactivity and collaboration and support the provision of information and resources for students and schools.

Meanwhile, The researcher agreed with the opinion of Chen and Jones (2007) [12], there is a wide range of research studies had been found that the blended learning approach has positive effects on student achievement, while other studies have indicated that blended learning achieves levels of student success equivalent to traditional education.

In the same as, Fig. 1 Main Types of Blended Learning in Institutions identify three main types of blended learning in institutions of education, as illustrated in Fig. by Najeh Rajeh Alsalhi (p.3.in Ross and Gage, 2006, p.156, p.156) [13] the author agreed to the differences between traditional learning and blended learning as shown in fig. 1

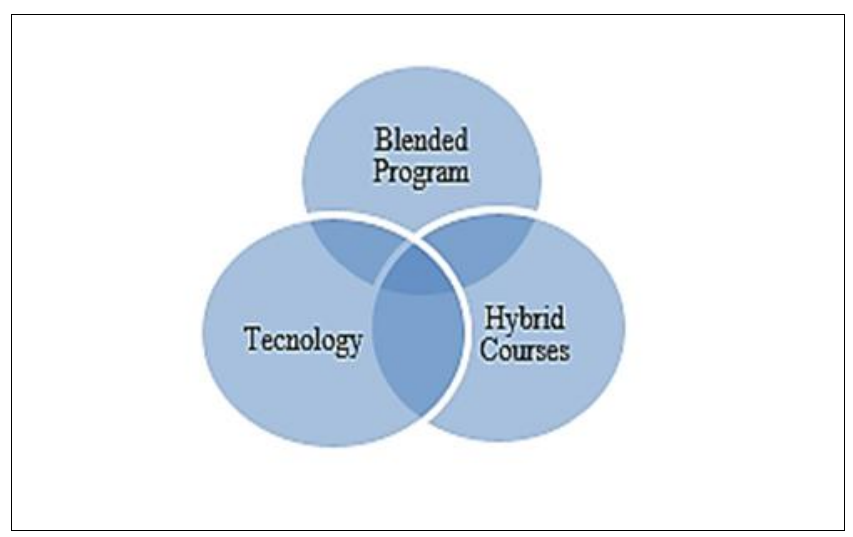

Fig. 1 Main Types of Blended Learning

Based on the above discussion, the authors can conclude that blended learning combines not only the two modes of teaching but also how to improve the quality of the teaching and learning process, helping students to excel in their learning goals and learning experiences.

Then, the authors discuss the above steps in the following: 1 . make a planning learning model, 2 . the content, 3. learning resources, 4. learning activities, and assessments. These elements are essential tools for an important mixed learning process. Teachers also need to consider their classroom situation and learn the goals they will achieve.

A survey method, taking a sample of 31 students using a questionnaire as the main data collection tool. By giving 15 questions related to student motivation in learning English, it can be seen in terms of integrative orientation and instrumental orientation, intrinsic, and extrinsic. Integrative orientation is the motivation to learn English because it is very interested in this subject in connection with the hobby of singing in English or likes to talk like a favorite English speaker.

Orientation instrumental motivation of students to learn English because they are aware of the importance of English in order to get a better job or want to continue their higher 
education abroad. Intrinsic motivation is the motivation to learn English because of the urge to be actively involved in learning activities, the urge to study independently, while extrinsic motivation is the urge to get praise from the teacher, the urge to please parents, and the drive to get good grades. Student motivation in learning English through blended learning is carried out with a research instrument in the form of a questionnaire distributed to students in the form of Google form. Based on selected questions related to data collection distributed to 31 respondents then recapitulated. From 31 respondents obtained using the calculation data Likert scale to measure Motivation in Learning English through Blended- Learning in the Department of Electrical Engineering Manado State Polytechnic.

Based on the item, the respondent will choose a number from 1 to 5 using the criteria strongly disagree, moderately agree, neutral/no opinion, moderately disagree, strongly agree. There are four kinds respond of students that represents how they feel about Learning English through Blended- Learning.

Table 1. Likert scale

Four kinds respond of students that represents how They feel about Learning English through Blended-Learning

\begin{tabular}{|l|l|l|l|}
\hline $\begin{array}{l}\text { Student } \\
\text { Motivation }\end{array}$ & $\begin{array}{l}\text { Strongly } \\
\text { disagree }\end{array}$ & $1-2-3-4-5$ & $\begin{array}{l}\text { Strongly } \\
\text { agree }\end{array}$ \\
\hline $\begin{array}{l}\text { Student } \\
\text { Attitude }\end{array}$ & $\begin{array}{l}\text { Strongly } \\
\text { disagree }\end{array}$ & $1-2-3-4-5$ & $\begin{array}{l}\text { Strongly } \\
\text { agree }\end{array}$ \\
\hline $\begin{array}{l}\text { Parent } \\
\text { Motivation }\end{array}$ & $\begin{array}{l}\text { Strongly } \\
\text { disagree }\end{array}$ & $1-2-3-4-5$ & $\begin{array}{l}\text { Strongly } \\
\text { agree }\end{array}$ \\
\hline $\begin{array}{l}\text { Student } \\
\text { Worried }\end{array}$ & $\begin{array}{l}\text { Strongly } \\
\text { disagree }\end{array}$ & $1-2-3-4-5$ & $\begin{array}{l}\text { Strongly } \\
\text { agree }\end{array}$ \\
\hline
\end{tabular}

Table 2: Tabulation Data

\begin{tabular}{|l|r|r|r|r|}
\hline $\begin{array}{l}\text { Likert } \\
\text { Score }\end{array}$ & $\begin{array}{l}\text { Student } \\
\text { Motivation }\end{array}$ & $\begin{array}{l}\text { Student } \\
\text { Attitude }\end{array}$ & $\begin{array}{l}\text { Parent } \\
\text { Motivation }\end{array}$ & $\begin{array}{l}\text { Student } \\
\text { Worried }\end{array}$ \\
\hline $\begin{array}{l}\text { Strongly } \\
\text { Agree }\end{array}$ & $56 \%$ & $23 \%$ & $44 \%$ & $20 \%$ \\
\hline $\begin{array}{l}\text { Moderately } \\
\text { Agree }\end{array}$ & $20 \%$ & $21 \%$ & $23 \%$ & $26 \%$ \\
\hline Neutral & $21 \%$ & $29 \%$ & $21 \%$ & $21 \%$ \\
\hline $\begin{array}{l}\text { Moderately } \\
\text { Disagree }\end{array}$ & 0 & $22 \%$ & $3 \%$ & $28 \%$ \\
\hline
\end{tabular}

The results obtaine based on the responses from respondents are shown in figure 2 , and 3

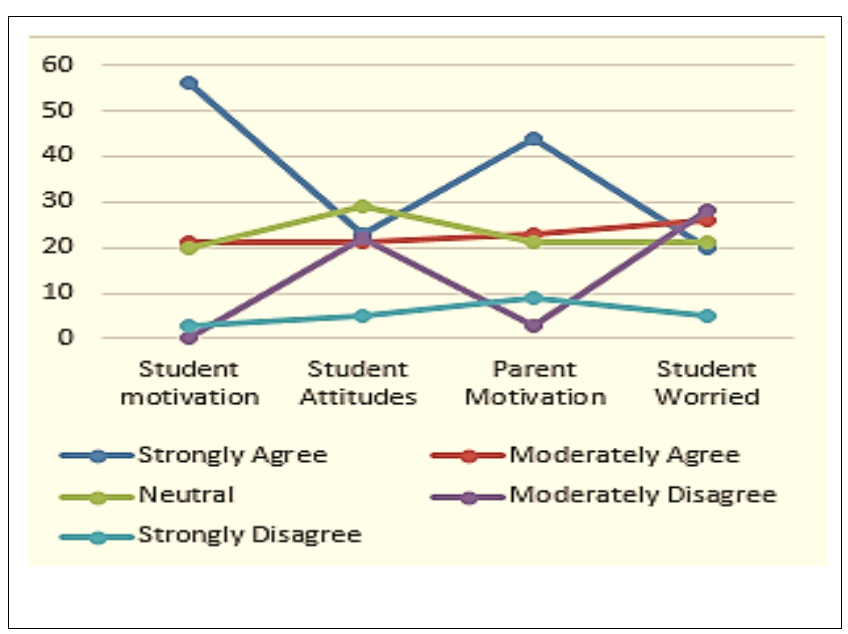

Fig 2. Student motivation

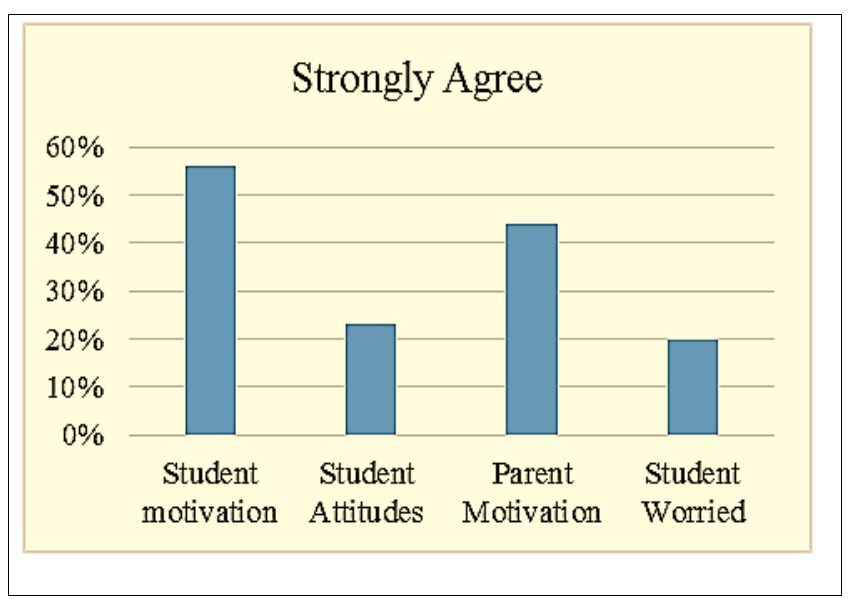

Figure 3. Student Strongly Agree 56,48\%

Statement 1 states that students' motivation strongly agrees $(56 \%)$ and moderately agrees $(20 \%)$ that they are interested in online learning activities. Other respondents moderately disagreed $(21 \%)$ neutral $(0)$ and strongly disagreed (3\%) with online learning activities.

Statement 2, students' attitudes towards blended learning strongly agree $(23 \%)$ and moderately agree $(21 \%)$ that they are interested in online learning activities. Other respondents disagreed (29.7\%) neutral (22) and moderately disagreed (5\%) with online learning activities.

Statement 3. Most respondents strongly agree (44\%) and moderately agree in the table above, the students were taught the topics academic electrical engineering textbook English book using direct teaching (traditional teaching).

Statement 4. Most respondents who worried strongly agree (20\%) and moderately agree (26\%), Neutral (21\%0, Moderately Disagree (28\%) and Strongly Disagree (5\%).

The experimental group was taught the same material using blended learning. The material was taught during the second semester of 2020 year. The models are detailed in Table 3.

Table 3. Blended learning and traditional learning.

\begin{tabular}{|l|c|l|}
\hline Feature & $\begin{array}{c}\text { Tradisional } \\
\text { Learning }\end{array}$ & Blended Learning \\
\hline Location & Classroom & Any place and flexible \\
\hline
\end{tabular}




\begin{tabular}{|l|c|l|}
\hline Method & Face to face & Online and face to face \\
\hline Time Learning & Specific Time & $\begin{array}{l}\text { Time Flexible and Any } \\
\text { Time }\end{array}$ \\
\hline Usage Technology & $\begin{array}{c}\text { Using } \\
\text { Tecnology }\end{array}$ & Using the technology \\
\hline
\end{tabular}

In the table above, the students were taught the topics Academic electrical engineering textbook English book using direct teaching (traditional teaching). The experimental group was taught the same material using blended learning. The material was taught during the second semester of 2020 year.

Khamis (2003)[14], blended learning is an integrated system designed to assist students in every stage of their learning by using traditional learning with e-learning in its various forms in the classroom.
Kavitha and Jaisingh (2018) and Singh (2003)[15] say that blended learning is a form of e-learning where e-learning is integrated into traditional classroom learning, using computers, intranets, or smart classrooms, where teachers meet. Student face-to-face and student-teacher interactions are incorporated into the course design. It came about as a natural progression of programmed and electronic learning. From the previous definition of blended learning, the researchers identify mixed learning as a new blending learning strategy traditional learning

in its various forms, and e-learning in its various forms model, to increase student motivation and enhance their learning implementation, as shown in Figure 4.

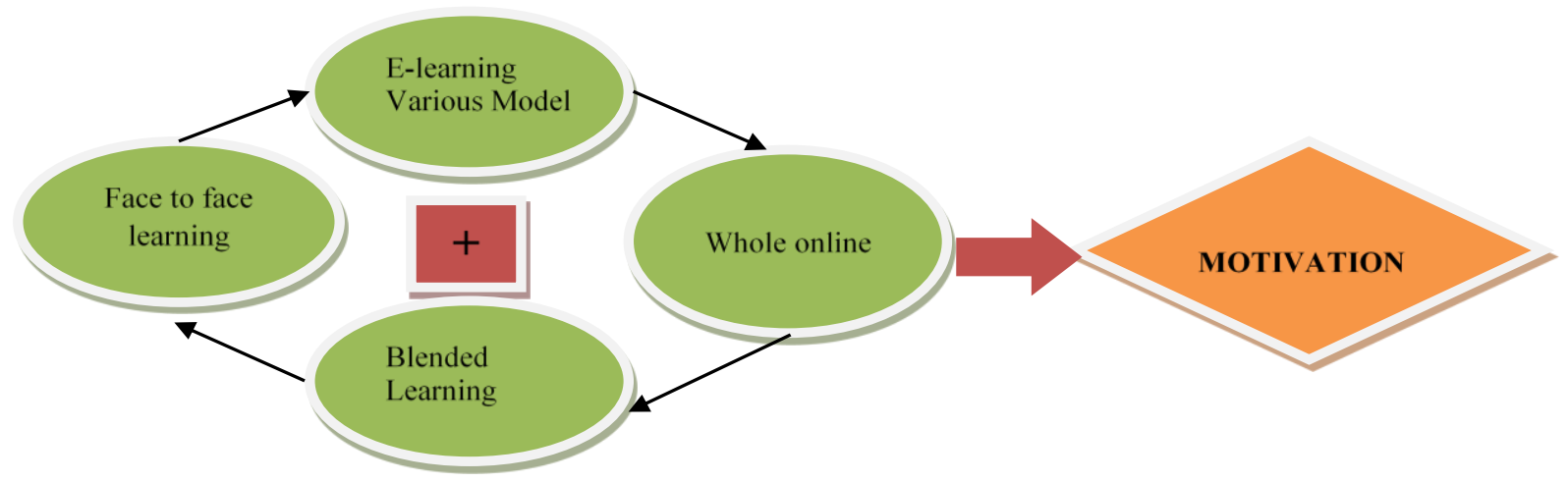

Fig 4: Roadmap for Implementation of Blended Learning

\section{CONCLUSION}

Based on the results of tests on 31 students majoring in electrical engineering, the survey results showed 56, 48\% which having interpretation "enough" for students get motivation in learning English through Blended-Learning.

Motivation through blended-learning is in great demand because it uses various learning media such as interesting videos, interactions through zoom meetings, and displays images that are closely related to student study programs.

The main findings indicate that the respondents were relative "very" motivated a little more "integrative" for learning English. This reveals that motivational blended learning is a significant factor for students to learn English.

This study is very important because blended learning is effective in education in higher education. This model is recommended more effective than face-to-face interaction in courses that contain more visual elements..

\section{ACKNOWLEDGMENTS}

This research was supported by Politeknik Negeri Manado, We thank Director of Politeknik Negeri Manado. The head center of P3M Politeknik Negeri Manado supporting and provide insight and expertise that greatly assisted this research. Dr. Tineke Saroinsong SST, M. Eng..

\section{REFERENCES}

[1] Brown H. Douglass (2008) Prinsip Pembelajaran dan Pengajaran Bahasa.Jakarta: The Public Affairs Section U.S.Embassy
[2] Borg, W. R., \& Gall, M. D. (1989). Educational research: an introduction (4th Ed.). New York: Longman.

[3] Gardner R.C (2004) dalam European Journal of Foreign Language Teaching Vol.3 Issue4,2018. Idham Kholid, (2017)

[4] Idham Kholid. English Education: Jurnal Tadris Bahasa Inggris p-ISSN 2086-6003 Vol 10 (1), 2017, 61-71

[5] Munaiseche M.dkk. (2019) "Effectiveness Blended Learning on the Motivation of Electrical Engineering Student's Toward Speaking Ability. Proceeding Seminar terapan Nasional Vol.5.2019.

[6] McPheat, Sean. (2010). Motivation Skills. UK: MTD Training \& Venus Publishing ApS

[7] Munaiseche Maya, P. G. (2018). Analysis of English skill obstacles of electrical engineering students of Politeknik Negeri Manado. Journal of Applied Studies in Language, Volume 3 Issue 1 (Jun 2019), p. 63-70 p-issn 2598-4101 e-issn 2615-4706 Politeknik Negeri Bali

[8] Saliba, G. (2013). Fundamentals of Blended Learning. Sydney: University of Western Sydney

[9] https://www.researchgate.net/publication/324561632.

[10] Saliba, G. (2013). Fundamentals of Blended Learning. Sydney: University of Western Sydney

[11] Bath, D. \& Bourke, J. (2010). Getting started with blended learning. GIHE: Griffith Institute for Higher Education. 
[12] Chen, C., Jones, K., 2007. Blended learning vs. traditional classroom settings: assessing effectiveness and students' perceptions in an MBA accounting course. J. Educ. Online 4 (1), 1-15.

[13] Najeh Rajeh Alsalhi, et all (2019). The effect of blended learning on the achievement of ninth grade students in science and their attitudes towards its use. Heliyon 5 (2019) e02424. Published by Elsevier Ltd.
[14] Khamis, M., 2003. Products of Educational Technology. Dar Al Kalima, Cairo. Khan, A.I., Shaik, M.S., Ali, A.M., Bebi, C.V., 2012. Study of blended learning process in education context. Int. J. Mod. Educ. Comput. Sci. 4 (9), 23

[15] Kavitha, R., Jaisingh, W., 2018. A study on the student experiences in blended learning environments. Int. J. Recent Technol. Eng. 7 (4S), 2277-38. 